\title{
CSR EFFECT ON MARKET AND FINANCIAL PERFORMANCE
}

\author{
Dian Masita Dewi \\ Fakultas Ekonomi dan Bisnis Universitas Brawijaya \\ Jl. MT Haryono No. 165 Malang \\ cintachita1@yahoo.co.id
}

Abstract

This study aims to predict causality model [33] effect of Corporate Social Responsibility on financial performance. This study also examines motivation of CSR implementation based on financial performance and market performance in non-financial public companies and banks that disclose CSR activities and listed at Indonesia Stock Exchange during 2007-2009. Numbers of samples were 46 companies. Data was analyzed by GSCA. Research result showed that there was a significant direct effect between CSR on Return on Assets (ROA), Return on Equity (ROE). In contrast, there was no significant direct effect between CSR on Market Value Added (MVA). In addition, there was a significant direct effect between Return on Assets (ROA) on CSR, Return on Equity (ROE) on CSR and there was no significant direct effect between Market Value Added (MVA) on CSR. There were three empirical findings novelties of this study. First, return on assets (ROA) has positive effect on CSR and otherwise CSR has positive effect on ROA. Second, ROE has positive effect on CSR and otherwise CSR has positive effect on ROE. Last, MVA affect on CSR and otherwise CSR affect on MVA.

Keywords: CSR, financial performance, market performance

Basically natural character and motivation of any company or business was looking for maximum benefit. To achieve these objectives company often ignores welfare of employees, community, and natural environment (Suman, 2010) [26]. 
Existence of company or business also has a negative effect/industrialization inequality (negative externalities), ranging from deforestation, air and water pollution, to climate change. Company violation in Indonesia was on right to economic, social and cultural, as in of Lapindo mudflow in Sidoarjo, Buyat pollution caused by waste from PT.NMR Minahasa mine), and etc. [31]. Industrialization inequality (negative externalities) makes company have a responsibility more broadly, until social and environmental responsibility (corporate social responsibility/CSR).

Corporate social responsibility (CSR) was "company's obligations to use resources in beneficial manner to society, through committed participation as a member of society, by improving society welfare in general, which was funded through company's direct benefit" [30]. There were interesting questions related to CSR implementation, namely why companies disclose their CSR activity (Corporate Social Responsibility Reporting/CSRR)? A previous research show that companies that report social responsibility information (hereinafter abbreviated to CSRR/Corporate Social Responsibility Reporting) was increasing in its annual report ([12], [11]). Study [3] showed that one reason management did CSRR was for strategic reasons. It stated that one of approaches used in implementing the CSRR was motive approach [24]. It means companies did CSRR departed from company's expectations for obtain feed back, primarily economic (trade considerations of cost and benefit).

Many theories can be considered to explain company's motives to report CSR activities. This assumption was emphasized by stating that there were no specific theories that can explain behavior or company motivation in CSR implementation [8]. However, there were two leading theories were considered to explain motivation companies in implementation CSR, Legitimacy Theory and Stakeholder Theory [21]. Legitimacy Theory and Stakeholder Theory used in this study to provide basic framework of company's motivation to implement CSR in Indonesia. Essence of legitimacy theory was to ensure and maintain alignments (legitimacy) both for internal and external stakeholders, companies need to ensure congruence between existence and objectives of stakeholder's expectations ([11], [8], and [21]. It was consistent with stakeholder theory which explains that company's existence can not be separated from stakeholders. Stakeholders directly or indirectly affect and affected by company.

Indonesia corporate social responsibility reporting was voluntary disclosure. This was stated in Statement of Financial Accounting Standards No. 1 (2007) ninth paragraph that company can present additional statements such as statements regarding environment and value added statement, especially for industries where environmental factors play an important role and for industry which considers employees as users group that playing an important role. However, regulations in Indonesia regarding social and environmental activities of company had a significant change after the issuance of Law No. 40 of 2007 on Limited Liability Company 
which replaces Law No. 1 of 1995. This Act explicitly requires company and its business in natural resources to implement social and environmental responsibility (Article 74 paragraph 1) as well as requiring all company to report implementation of social and environmental responsibility in company's annual report (Article 66 paragraph 2). It means company Law No. 40 in 2007, CSR implementation and its reporting was mandatory. In July 2007, Indonesia was the first country to announce a mandatory law regarding CSR, which applies to companies using natural resources (CSR Asia 2007).

Determination of Company Law No. 40 of 2007 in Indonesia seems still was not a major effect on CSR activities and reporting on companies listed at Indonesia stock exchange. In 2009 only 33 percent from 392 major companies in Indonesia were doing CSR. It appears that Indonesia lagging on CSR practices should be observed. It revealed that CSR implementation in Indonesia seem as bad action because it applied when company compensate losses suffered by many parties through action programs for local community [23].

CSR and its reporting relationship to company's financial performance in Indonesia were very important. Since enactment of Company Law No. 40 year 2007, along with the reporting of CSR funds deducted as operating expenses that affect production costs and potentially decrease ability of company's competitiveness. This shows that companies in Indonesia still think about it because they were afraid of including implementation CSR will hurt company in a short period of time.

Empirical proving about partial relationship financial performance on CSR led to a diverse and interesting phenomenon to be studied more deeply. Several studies have found a positive effect, negative even no effect (neutral), as in study [30], [25]).

Perspective to a positive correlation between CSR and financial performance from [29] shows that companies with social and financial performance (ROA and ROE) tend to do good social disclosure extensively. This study was consistent with study [5], [4]. It indicated that social performance reporting has positive effect on economic performance that shown in good company profitability (ROE, ROA) and stock market performance (market value) [5].

Using variable ROA, it demonstrated relationship between CSR and financial performance. Study [13] proved positive effect between CSR with ROA although its value was very small.

ROE was used to obtain relationship between CSR and financial performance. ROE usage was very important, especially to see efficiency of company's financial performance. This explains positive effect between CSR with ROE, although its value was very small or 0.1 percent of CSR. This suggests that CSR can affect efficiency of company's financial performance (ROA) [22].

These results were contradictory to result of study [15] and [32] that there was a negative relationship between CSR and financial performance (ROA and 
ROE). This shows that CSR did not increase its profit and CSR activities make inefficient corporate performance. The reason was there will additional costs due to CSR disclosure. Thus, profitability will be dropped.

However [25] found that there was no effect of social disclosure or corporate social responsibility reporting on financial performance (profitability). This was caused by differences in CSR measurement, financial performance and number of samples selected.

Relationship between CSR and market performance was connected between CSR and financial performance, using variable market value added (MVA) to measure corporate economic performance (financial performance). This variable was used to view company's economic value added and also how efficient company in creating wealth for him and stakeholders. In 5th year study, it showed a positive correlation between market performance (MVA) on financial performance [19].

However, above studies makes contradictory results [22]. MVA variables used to examine relationship between market performance and contribution of company's investors. If positive, MVA adds value to company and investors and if negative, company declared value destroyed. MVA also considered able to show reputation of company's business activities and shows stakeholder responses to various company activities including corporate social activities. Research results show that MVA has a negative relationship to CSR or MVA decreases when CSR increases.

Study [19] relates Market performance and CSR, using market value added (MVA) to measure corporate economic performance (financial performance) with CSR. In his research there was a positive correlation between market performance (MVA) on CSRR.

Looking at empirical research context, as stated in the above-mentioned and referred to a study [33], it can be summarized that corporate social responsibility disclosure has good economic consequences on financial performance and market performance. The consequences were interdependent (reciprocal), which was a simplification of social company performance to legitimate stakeholders benefit and improve transaction profitability. Conversely, companies with high financial performance, in order to maintain the reputation and legitimacy, will try to improve its social performance reporting with social activity availability.

Gap phenomena of this study lies in differences in objects where objects of most previous studies companies in developed countries while this research was conducted in Indonesia, which with lot of cultural differences, socioeconomic level, and environmental control level. Differences also in the nature of execution, where execution of $\mathrm{R}$ in developed countries generally still voluntary because it was not regulated in CSR implementing with legislation binding but based on company's awareness of CSR importance and its reporting. While in Indonesia with the enactment of Company Law No. 40 of 2007 and CSR reporting was mandatory, however CSRD regulation was not supported by rules of advanced operational 
duties (such as reporting standards). This will cause the report vary between companies so difficult for reader to evaluate annual report of corporate social performance. Therefore, if reporting standards of CSR in Indonesia has not been established, this study used reporting standard from convergence of GRI Guidelines (GRI 3).

Research gap this research was on testing effect of openness consequences of Corporate Social Responsibility Reporting, especially in terms of economic (economic Consequences) that seen by financial performance (proxied by ROA and ROE) and market performance (proxied by MVA). The selection of this indicator was based on previous research. ROA (return on assets) was ratio of net income by total assets. Parameters used in this study from [4], [30] and [25], and ROE was calculated with net income divided by equity as a proxy of financial performance. This parameters used in study of [5], [30]. While Market performance variables in this study proxied by MVA (Market Value Added). MVA parameters used in this study come from [19] and [13].

Previous studies connect CSR on company's performance (financial performance and market performance) in partial manner. Based on positive synergy relationship model adopted from study [33], relationship CSR was not only partial but rather interdependent (reciprocal). In addition, previous research suggests that effect varied greatly in CSR implementation on financial performance and market performance, as well as effect of financial performance and market performance of CSR. Accordingly, it was expected that this study findings provide CSR; especially in Indonesia has a positive effect on firm performance listed on Stock Exchange. Adversely, improved financial performance will motivate companies to improve corporate social performance (CSP) through increased Corporate Social Responsibility Reporting Disclosure.

Therefore, this study aims to predict causality model [33] related to Corporate Social Responsibility performance effect on financial performance. This study also examines motivation CSR implementation based on financial performance and market performance of non-financial public companies and banks that disclose CSR activities and was listed at Indonesia Stock Exchange during 2007-2009.

Corporate accountability paradigm moves from shareholders orientation to stakeholder's orientation. The condition of negative externalities arises from widespread industrialization. The shift pattern will change company liability. Originally measured economically (economic measurement) then shift towards accountability that takes into account social factors (social measurement), hereinafter referred to corporate social responsibility.

Legitimacy theory and stakeholder theory provides a basic framework paradigm shift to stakeholders orientation. Essence of legitimacy theory was to explain to ensure and maintain alignments (legitimation) stakeholders, both internal and external. Companies need to ensure congruence between existence and objectives of 
stakeholder's expectations ([11], [8], and [21]). It was consistent with stakeholder theory principle that explains company's existence can not be removed from stakeholders. Stakeholders were a group or individual who can affect, or be affected by success or failure of an organization.

Study [21] states that company legitimacy stakeholders can be done and improved through strategies such as legitimacy and openness of corporate social responsibility in CSR Reporting (CSRR). Company alignments through social activities on society and environment need to be disclosed to parties concerned. CSRR was part of legitimation strategy implementation and realization of corporate accountability and business implications as well as efforts to maintain congruence corporate values to community; this was consistent with legitimacy principle and stakeholder theory.

Social responsibility practice has content motive, namely social and economic motive. Social responsibility has benefit to improve social performance, increase legitimacy, and attention with benefits to increase transactions and investor attention [34].

There were two things that can encourage companies to implement CSRR namely from outside company (external drivers) and from within company (internal drivers). Outside was driving force of regulations, laws, and mandatory environmental effect assessment. Formal judicial in Indonesia issued several regulations related to important changes in terms of CSR reporting. Government regulation through Act No. 40 of 2007 on Limited Liability Companies, requires that natural resources business should implement social and environmental responsibility (Article 74 paragraph 1), and requires that all of company has responsibility to report implementation of social and environment at company's annual report (Article 66 paragraph 2).

Bapepam with Decision No. 134/BL/2006 expressed about obligation to submit annual reports for issuers and public companies, require companies to describe activities and costs associated with corporate social responsibility towards society and environment.

Another regulation regarding CSR was Law No. 25 of 2007 on Investment, which in Article 15 (b) states that every investor was obliged to carry out corporate social responsibility, and Article 34 regulate in detail the sanctions against business entity or individual that ignore CSR.

Globalization triggers fierce competition in seizing Market (consumers). Economic market was a market where company won consumer emotions. Furthermore, it stated that company's success can be built to establish good relations with customers and provide an understanding and confidence in superior quality of products, reliability and service to consumers. It was asserted that corporate social responsibility expenditure, as charity, philanthropic and community development, can increase trust and transactions [14]. 
There were three values that should be built in order go public company become a market leader, namely: (1) operational excellence, customer-oriented by providing a low cost and high quality products and services, (2) product leadership, by providing product customers want, and (3) customers intimacy, with detailed explanations of health information, utilization and product quality assurance. The three strategies were dimensions of social responsibility to consumers that expected to increase proximity of health and insurance company to consumer [14].

Study [34] provides confirmation that company with customer and employee orientation likely to have good financial or economic performance. Companies that have alignments to consumers and employees will get legitimacy so they will support company's strategy to improve its financial performance.

Financial performance variables used was return on assets (ROA) and return on equity (ROE). The level of corporate social responsibility was expressed through disclosure level of their social activities (including social costs) that may increase company legitimacy. Companies legitimacy makes benefit by increasing financial transactions to increase profitability. It shown in ROA and ROE.

Efforts to maintain and improve ROA and ROE are done with supporting people [5]. Company alignments to environmental spending can improve financial performance. It shown in ROA and ROE values [6].

Study [27], [28] explained that ROA and ROE considerations can be used in measuring financial performance of company, in addition to increase net income and a dividend payout ratio. It was proved that higher ROA and ROE value means higher company performance. This indicates that company was worthy in investors consideration.

It shown that there was a relationship between environmental performances with financial performance [20]. From previous studies, relationship was not always generate positive but also negative relationship. It was influenced by many factors, such as media coverage and issues within community.

It demonstrated relationship between CSR and financial performance [32]. Using return on assets (ROA) and return on equity (ROE) of company's financial statements show financial performance. ROA indicates how companies increase profits by using total assets in specified period. If high ROA, it indicate that company can earn high profits from their own assets. Meanwhile, ROE shows how companies use their capital property. If ROE was high, then company management run efficiently.

Theoretically and empirically CSRR important for companies to build image, maintaining reputation and legitimacy of investor. Thus, company seeks to further expand scope of corporate social responsibility disclosure (CSRD), especially companies that have a good financial performance. CSR has economic consequences for company (CSR affect performance of Financial Performance and Financial Performance affect on CSR). 
From description above, hypothesis of this research were:

H1 : CSR has positive effect on company's financial performance (ROE) increase

H3 : Company CSRR level has positive effect on company's financial performance (ROA) increase

Hypothesis effect of financial performance on CSR was:

$\mathrm{H} 2$ : Increased Company's financial performance (ROE) has positive effect on CSR level

H4 : Increased Company's financial performance (ROA) has a positive effect on CSR level

Corporate Social Responsibility Reporting also provides investors certainty and security to invest in capital market. Social disclosure contains information that provides facilities for investors in making decisions. Furthermore, it stated that social disclosure information reduces uncertainty for investors (investor's informational uncertainly). Corporate Social Responsibility Reporting has differential effect on monthly stock price [2]. To maintain and enhance performance and reputation, including improving market performance, then company needs to do a set of strategies such as legitimacy by doing Corporate Social Responsibility Reporting [10]. This was consistent with opinion of [1] which states that there was a link between market performances with Corporate Social Responsibility Reporting. Opinions proficiency level meant that effort required maintaining company legitimacy and a good transaction in commodity market and equity market by Corporate Social Responsibility Reporting.

It explained that Corporate Social Responsibility Reporting can improve company's reputation and relationships in eyes of banker's, investors and government official [16]. CSR connect Market with market value added (MVA) [22]. MVA was used to examine relationship between market performance and contribution to company's investors. If MVA positive, company adds value to company and investors and, if negative, company declared the value destroyed. MVA also considered able to show reputation of company's business activities and shows stakeholder responses to various activities of company. 


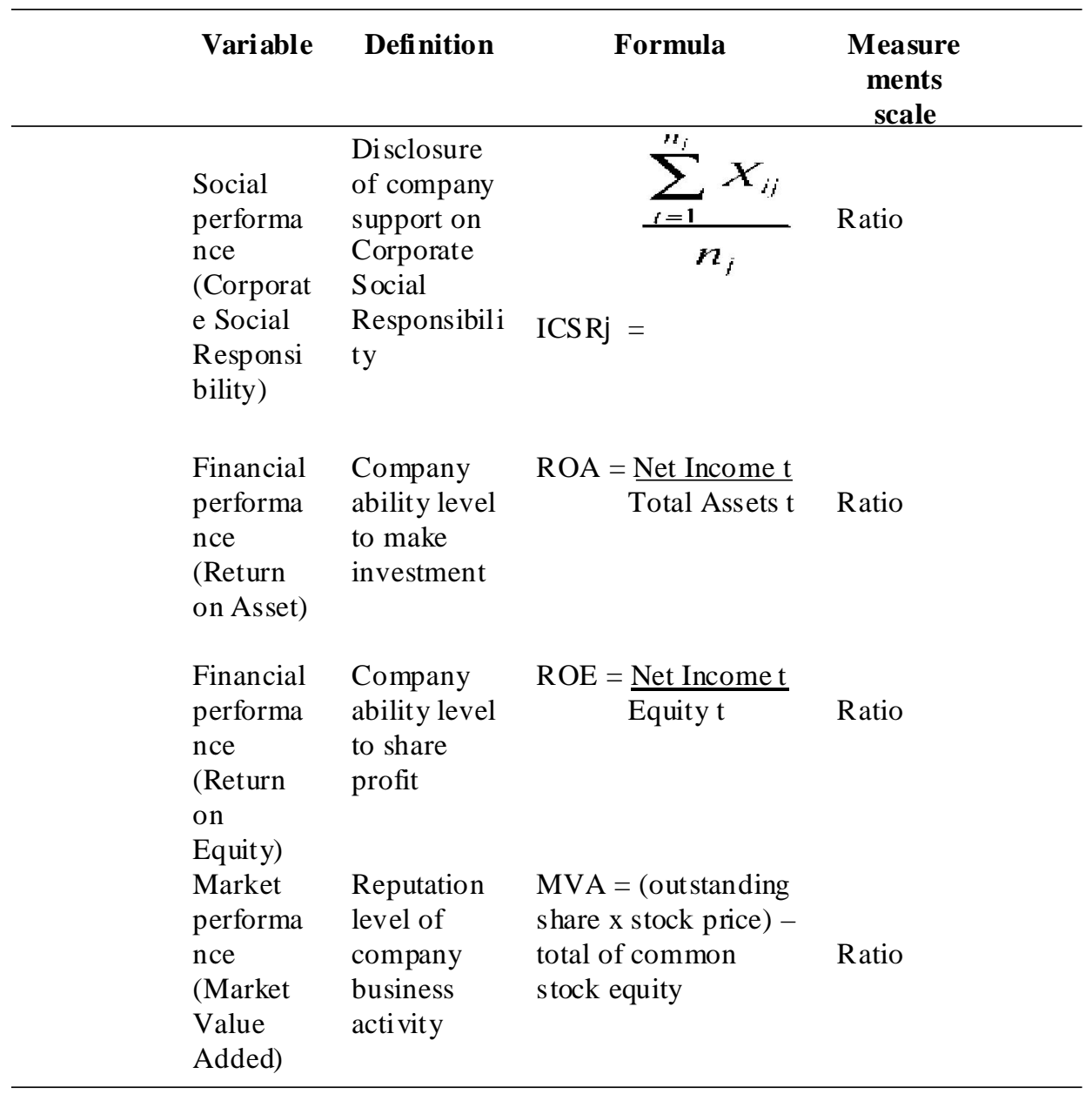

Theoretically and empirically, for investors, CSR was used as information media and business atmosphere evaluation susceptible level claims about company's stakeholders. This evaluation was importance related to hope and assurance of security investments from expected return on investment that has been made.

Theoretically and empirically, CSR was important for a company to build image, maintaining reputation and legitimacy of investor. Looking at result of study as stated above, it can be summarized that there was interdependence between desire responsibility expressed with motif social (social disclosure) and maintaining company's financial performance. Openness level and responsibility (social disclosure) show company information with economic consequences (economic consequences). It provides opportunities to increase transactions, profitability and market value. Adversely, a company that has a good financial performance in order to maintain the reputation and legitimacy will be motivated to take a broad range of social 
disclosure (extents of Social Reporting. (CSR ® MP and MP ® CSR). From description above, hypothesis of this research were:

H5 : Company CSR level has positive effect on market performance increase (MVA).

H6 : Company market performance (MVA) has a positive effect on CSR level.

\section{Methods}

This was explanatory research with quantitative approach. The data presented was figures that calculated through statistical tests. This research was conducted in Indonesia Stock Exchange. Research object was the entire company; exclude non-financial companies and banks, listed at Indonesia Stock Exchange (IDX) during 3 years observation (2007-2009). All 46 populations become sample (census method). Based on above explanation, analysis unit in this study was non-financial and banks companies. This study uses secondary data from multiple sources follows

- Indonesian Capital Market Directory 2007-2009.

- Company's annual report (annual report) and published continuously from 20072009.

- Official website of company (www.idx.co.id).

- This study uses variable index of Corporate Social Responsibility (ICSR), return on equity (ROE), return on assets (ROA), and market value added (MVA). Descriptions were presented in table below.

\section{Table 4.2. Operational of Research Variable}

Source: Adapted by researcher

Statistically inferential methods that used to analysis data were Generalized Structural Component Analysis (GSCA). Structural model of GSCA was testing hypothesis on each path. Test results of structural model on complete hypothesis were presented in following figure. 


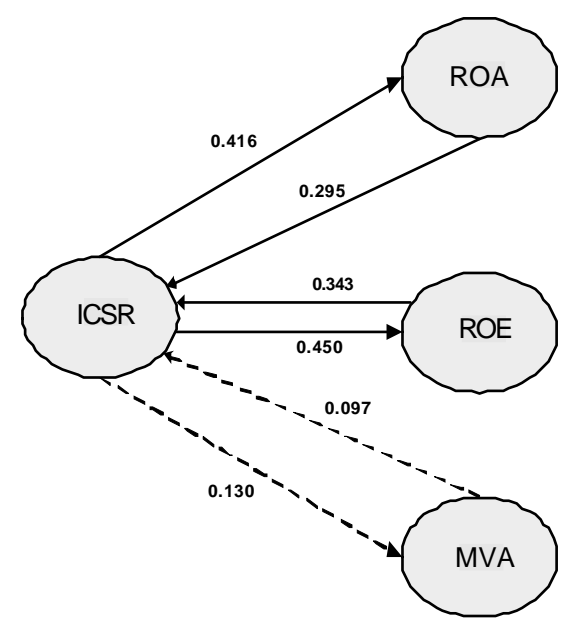

Figure 5.5. Structural Model Results: Direct Effect Hypothesis Testing

From test results above, results can be explained as follows:

- $\quad$ Direct affect of ICSR on Return on Assets (ROA) produces path coefficient of 0.416. Value of Critical Ratio (CR) at 3.58 and p-value of $0.000 \mathrm{CR}>1.96$ and p-value>0.05. It means there was a significant direct effect between the ICSR and ROA.

- $\quad$ Direct affect of ICSR on ROE produces path coefficient of 0.450 , with Critical Ratio (CR) of 5.41 and p-value of 0.000 . CR> 1.96 and p-value> 0.05 indicates there was a significant direct effect between ICSR and Return on Equity (ROE).

- $\quad$ Direct affect of ICSR to MVA produce path coefficient of 0.130 , Critical Ratio (CR) of 1.54 and a p-value of 0.124. CR <1.96 and p-value > 0:05 indicate that there was no significant direct effect between ICSR and MVA.

- Direct affect of ROA on ICSR produces path coefficient of 0.295, Critical Ratio (CR) of 2.45 and p-value of 0.014 . CR> 1.96 and $p$-value> 0.05 indicates that there was a significant direct effect between ROA and ICSR.

- $\quad$ Direct affect of ROE on ICSR generates path coefficient of 0.343 , with Critical Ratio (CR) of 3.39 and p-value of 0.014 . CR> 1.96 and p-value> 0.05 indicates that there was a significant direct effect between ROE and ICSR.

- $\quad$ Direct effect between Market Value Added (MVA) on ICSR produces path coefficient of 0.097, with a value of Critical Ratio (CR) of 1.50 and p-value of 0.134 . CR $<1.96$ and p-value $>0: 05$ indicate that there was no significant direct effect between Market Value Added (MVA) and ICSR.

From hypothesis from hypothesis 1 to 6 , there were two hypotheses rejected, namely hypothesis 3 and 6 . Adversely, hypotheses 1, 2, 4, and 5 were accepted. 


\section{ICSR effect on ROA}

Path coefficient analysis the affect of ROA on ICSR produces coefficients of $0.416, \mathrm{CR} 3.58$ with p-value of 0.000 . CR values $>1.96$ and $\mathrm{p}$-value $>0.05$ indicates that hypothesis $\mathrm{H} 1$ was accepted. It shows ICSR affect on ROA. It means that higher ICSR value could lead to higher ROA.

This study result indicates that alignments companies to public can increase ROA [5], and Alignments Company to environmental supports ROA [6]. This study result theoretically supports that Partisanship Company towards society and environment can improve financial performance.

The empirical results of this research support the research [13] that social performance reporting has positive effect on ROA. CSR was positively related to ROA. The empirical results show that CSR companies has a role to improve financial performance of company in form of ROA.

This study did not support study of [15] and [32], that there was a negative relationship between CSR with financial performance (ROA). ROA indicates how companies increase profits by using total assets in specified period.

This study result showed that CSR index can increase company's performance in form of ROA. CSR indexes provide support for company to build image, maintaining reputation and legitimacy of investors to increase capacity of company. This was consistent with statement of Kotler and Lee (2005) that participation in various forms of corporate social responsibility can provide many benefits for company. Benefits received by companies that participating in corporate social responsibility were: a) increasing sales and market share, b) strengthen brand positioning, c) improving image and company effect; d) improving ability to captivate, motivate, and retain employees; e) reduce operational costs, and increase investors desire to invest.

This study was conducted on 46 companies as study sample. In 2007, average ROA reached $15.1 \%$, highest score. In 2008 has decreased to $10.66 \%$, whereas in 2009 have increased compared to previous year of 12:16\%. Average ROA for 3 years reached $12.64 \%$, this was fairly good results for all 46 companies. This suggests that CSR has been able to provide good financial performance in form of good ROA.

\section{ICSR effect on ROE}

Path coefficient analysis the ICSR effect on ROE produces a coefficient of $0.450, \mathrm{CR}$ of 5.41 with a p-value of 0.000 . CR> 1.96 and $p$-value $>0.05$ indicates that hypothesis $\mathrm{H} 2$ was accepted that ICSR affect on ROE. It means that higher value of ICSR could lead to higher ROE.

ROE (return on equity) describes company ability to manage fund (capital) given by shareholder to make profit. CSR Index at 46 companies has been able to 
support achievement of ROE. It can be seen from ROE acquisition of 46 companies. Average ROE of company in 2007 was $28.97 \%$. In 2008, average ROE decreased to $18: 18 \%$, and in 2009 again increased to $23.85 \%$. On average during the 3-year rate average ROE reached 23.67\%. ROE Achievement was above central bank rate $(6 \%)$. ROE of $23.67 \%$ indicates that management was able to manage funds from shareholders, to generate ROE above $\mathrm{BI}$ rate. Bigger companies ROE mean company have good financial performance.

This study result supports [30], [32], [13] and [33], that performance of CSR and CSR reports Affect Company's financial performance (ROE). Many things affect fluctuation of return on equity (ROE). It was due to a variety of factors that occur, either within company or outside company. CSR disclosure index was a corporate social responsibility activity compared with disclosures required under Global Reporting Initiative (GRI 3). Disclosure of corporate social responsibility activities were reflected in CSR index. It has been able to provide trust of parties concerned with company to participate in company. They can easily give corporate debt, so that company can operate properly.

\section{ICSR affect on MVA}

Path coefficient analysis results the effect of MVA on ICSR produce a coefficient of $0.130, \mathrm{CR}$ of 1.54 with p-value of 0.124 . CR $<1.96$ and p-value $>0: 05$ indicate that hypothesis H3 was rejected that ICSR affect MVA.

Corporate Social Responsibility Reporting provides investors certainty and security to invest in capital market. Social disclosure contains information that provides facilities for investors in decisions making. Corporate Social Responsibility Reporting affects differential stock price on a monthly basis [2]. Companies through CSR strategy maintain and enhance performance and reputation, including improving market performance [1]. Corporate Social Responsibility Reporting relates to market performance. Corporate Social Responsibility Reporting improves company's reputation and relationships with banker, investors and government official [16]. This study result does not support previous research that Corporate Social Responsibility Reporting and CSR affect on market performance (MVA).

Sample of 46 research firms in 2007 reached an average 4.60 trillion rupiah MVA or lowest compared to other years. In 2008 increased at the highest point that was equal to 14:43 trillion, and in 2009 declined slightly to 12.77 trillion rupiah. MVA performance achievement demonstrates market fluctuations. Market performance (MVA) was used to measure effect of managerial performance since its establishment until now. Managerial performance was not only measured in the form of corporate social responsibility, but also many other aspects, especially related to equity returns. These results indicate that market performance (MVA) obtained by company was not based on company's CSR activities, but based on rate of return capital that has been invested by shareholders. 


\section{ROA affect on ICSR}

Path analysis results the effect of ROA on ICSR produce a coefficient of $0.295, \mathrm{CR}$ at 2:45 with a p-value of 0.014. CR> 1.96 and $p$-value> 0.05 . It indicates that hypothesis $\mathrm{H} 4$ that ROA affect on ICSR was accepted. It means that higher ROA makes higher ICSR.

Achievement ROA average of 46 companies during 2007 to 2009 was to $12.64 \%$. It indicates that company's total assets were used was able to produce earnings before interest and tax of $12.64 \%$. Acquisition ROA shows that 46 companies in sample have a huge opportunity to improve company's growth.

Result show ROA affect on CSR index. These results indicate that company's earnings growth improve corporate social responsibility. Corporate social responsibility was a strategy to meet stakeholder's interests and ensure long-term sustainability of company. ROA growth can be used to finance company's CSR activities. Furthermore, company can meet stakeholders and ensure company longterm sustainability.

Research result support research of [18], [2], [16], [1], [10], and [13]), that there was a positive relationship between ROA on CSRR level. ROA produced by company can be used to finance social responsibility (CSR) to company's stakeholders. If company did not generate sufficient ROA, company did not implement many social responsibility activities (CSR), due to limited funds owned. ROA pretty good achievement could provide a booster for company to carry out CSR activities towards stakeholders.

\section{ROE affect on ICSR}

Path analysis results between ROE and ICSR produce a coefficient of 0.343 , $\mathrm{CR}$ at 3.39 with a p-value of 0.001 . $\mathrm{CR}>1.96$ and p-value> 0.05 indicates that hypothesis H5 that ROE affect ICSR was accepted. It means higher ROE value will increase higher ICSR.

Return on equity (ROE) of 46 companies on average over 3 years to reach $23.67 \%$. Companies ROE was above BI rate (6\%). It suggests that Management Company was able to manage funds provided by shareholders to generate profits for shareholders. Confidence of shareholders depends on opportunities to receive profit from funds invested to company. Corporate profits as ROE was obtained through company profitability, efficient asset management, and debt used in management of business (financial leverage). Company's ability to obtain advantage as ROE can set aside their own funds to carry out activities of social responsibility (CSR) companies that can further ensure long-term sustainability of company.

Research result support research of [6], [5], [7], [17] [9], [14], [32], [13]), there was a positive ROE on CSR. IT shows that, theoretically and empirically, ROE affect positively activities of corporate social responsibility (CSR). 


\section{MVA affects ICSR}

Path analysis results between variables ICSR and MVA produces a coefficient of 0.097, CR at 1.50 with a p-value of 0.134 . CR $<1.96$ and p-value $>0: 05$ indicate that hypothesis H6 that MVA affect ICSR was rejected.

On average 46 companies sampled in 2007 show average MVA at 4.60 trillion rupiah, lowest compared to other years, in 2008 increased at the highest point at 14:43 trillion, and in 2009 declined slightly to 12.77 trillion rupiah. During 2007 to 2009 an average of 46 MVA firm showed fluctuations. It was caused by various factors, both internal and external. In 2009 highest achievement of 46 companies were 20.10 trillion rupiah while the lowest was -852 billion dollars. This suggests there were a variety of MVA produced by 46 companies. When linked with CSR index, ICSR of 46 companies showed highest value in 2009 of 0.76 and lowest value of 0.08 . This suggests that corporate social responsibility activities were less reflected in ICSR an effect on market value added (MVA), which was produced by company. This situation can be seen from result of MVA achievement. Still there were companies that get negative numbers even though company had engaged in corporate social responsibility (CSR).

This study result does not support [19], that accountability to shareholders through market value added (MVA) will encourage companies to implements corporate social responsibility activities (CSR). Stakeholder perceptions of corporate reputation through company were expected to consider the achievements of not only financial but also environmental and social performance. CSR activities of company was no longer oriented to market value added (MVA), but to reputation of company to participate in building social relationships with stakeholders with long-term oriented. So that achievement of market value added (MVA) has no effect on social responsibility (CSR). Market value added (MVA) did not directly increase activity of social responsibility (CSR). Achievement of market value added (MVA) of high activity has not increased social responsibility (CSR) companies, while companies that market value added (MVA) lower increase social responsibility activities (CSR) companies, this was done because CSR was a company's strategy to ensure sustainability long term.

\section{New Findings}

- Return on assets (ROA) has positive effect on ICSR and otherwise ICSR has positive affect on ROA. This study result has not been done by previous investigators with regard to reciprocal relationship between ROA and ICSR.

- Return on equity (ROE) has positive effect on ICSR and otherwise ICSR otherwise has positive effect on ROE. Reciprocal relationship between ROE and ICSR has not been done before, so this study was important to findings look interrelationships between ROE and ICSR. 
- $\quad$ Market value added (MVA) affect on ICSR and otherwise ICSR affect on Market value added (MVA). Result showed that MVA did not have significant effect on ICSR and vice versa.

\section{Conclusion}

Based on research findings, it can be concluded as follows.

- Index of corporate social responsibility (ICSR) was a measure of corporate social activity towards stakeholders. Result showed that index of corporate social responsibility (ICSR) affect to improve Return on assets (ROA) of company. In addition, return on assets (ROA) has an effect to improve company's corporate social responsibility index (ICSR). These results indicate the existence of mutual affect between corporate social responsibility index (ICSR) with return on assets (ROA), and return on assets (ROA) with an index of corporate social responsibility (ICSR).

- Index of corporate social responsibility (ICSR) was associated with a return on equity (ROE) and also shows a reciprocal relationship. Increased corporate social responsibility index (ICSR) affect to improve corporate return on equity (ROE). Furthermore, increase in return on equity (ROE) can increase index of corporate social responsibility (ICSR). Implementation of corporate social responsibility (CSR) can affect financial performance too improve return on equity (ROE). Increase in return on equity (ROE) was used to be allocated in social activities (CSR) of companies that produce an increase in Corporate Social Responsibility (ICSR). Interrelationship of corporate social responsibility index (ICSR) with return on equity (ROE) shows that corporate social responsibility (CSR) can provide economic effect for companies associated with improved financial performance in particular return on equity (ROE).

- Index of corporate social responsibility (ICSR) relationship with a market value added (MVA) showed different results. ICSR carries less effect to increase market value added (MVA). Conversely, an increase in market value added (MVA) has no effect on corporate social responsibility index (ICSR). These results indicate that corporate social responsibility (CSR) was less effect to increase in market value added (MVA). Where Market value added (MVA) was not only determined by the social activities of company (CSR) but from the aspect of corporate performance and economic aspects, so that corporate social responsibility was less effect on increasing Market value added (MVA). Increase in market value added (MVA) was not directly generate direct financial gain, so it can not be used to increase company's social activities. 


\section{Research implications and future research suggestions}

Research implication could be stated as follow.

- Company in Indonesia Stock Exchange (IDX) should expand proportion of a corporate social responsibility (CSR). CSR was directed to improve corporate environment, and providing social assistance to employees to improve the education and skills. Besides that corporate social responsibility was more geared to awareness-raising and public health education that still needs to be improved.

- Social activities by company not only to fulfill obligation, but rather to provide improved general welfare of society and ultimately will benefit socially and economically. This study result were associated with market value added (MVA), it was expected that companies can increased market value added (MVA) to provide adequate resources allocation in corporate social responsibility (CSR).

- Indonesia Stock Exchange (IDX) should makes more promotion to listed companies to participate in CSR. Increased promotion would change of company mindset as well as the important role in supporting social by company in order to improve the quality of human resources and subsequently may indirectly increase general economy, and ultimately increase Market for company.

- Government always promote corporate social responsibility program to all companies in Indonesia. This was done to increase participation of companies to participate and address the social problems faced. Company participation was expected to solve social problems in society. Better community social life will support business climate and ultimately can provide economic benefits for company.

There were several weaknesses that need to be delivered. This study did not distinguish companies with positive and negative ROA, ROE and MVA positive and negative toward ICSR. So this research result were less able to get an idea of whether positive ROA, ROE and MVA have more affect on ICSR than negative ROA, ROE and MVA. Further research can compare effect of company with ROA, ROE and MVA positive and negative on ICSR

Study also did not distinguish between the companies that exploit natural resources and do not exploit natural resources. For companies that exploit natural resources, social responsibility was something that should be done, so that research results can be known whether companies that exploit natural resources have ROA, ROE and MVA with a greater effect on ICSR. Future studies can be developed with compare companies that exploit and not exploit natural resources. 


\section{REFERENCES}

Adams, C.A. 2002. Internal Organizational Factors Influencing Corporate Social and Ethical Reporting Beyond Current Theorizing, Accounting, Auditing and Accountability Journal, 15:2.

Anderson, J.C., and Frankle, A.W. 1980. Voluntary Social Reporting: An Iso-Beta Portfolio Analysis, the Accounting Review, 55:468-79.

Basalamah, A.S., dan J. Jermias. 2005. Social and Environmental Reporting and Auditing in Indonesia : Maintaining Organizational Legitimacy? Gajah Mada International Review Volume, 14:107-125.

Belkaoui, A., and Karpik, P.G. 1989. Determinants of Corporate Decision to Disclose Social Information, Accounting, Auditing and Accountability Journal, 1:1.

Bowman, H. 1978. Strategy, Annual Report and Alchemy, California Management Review, 20:64-71.

Bragdon, J.H., and Marlin, J.U.A.T. 1972. was Pollution Profitable. Risk Management. 19:9_ 18.

Chen, Kevin, C.W. Zhihing Chen, and K.C. John Wei. 2009. Legal Protection of Investor, Corporate Governance and Cost of Equity Capital. Journal of corporate finance Volume 15:273-289.

Deegan, C. 2002. Introduction - the Legitimizing Effect of Social and Enviromental Disclosure-A Theoretical Foundation. Accounting, Auditing and Accountability Journal, 15:182-311.

Freedman, M., and Jaggi. 1992. An Analysis of Association Between Pollution Disclosure and Economic Performance, Accounting, Auditing and Accountability Journal, 1: 6-20.

Fry, F., and Hock, R.J. 1976. Who Claim Corporate Responsibility? the Biggest and the Worst, Bussiness and Society Review/Innovation, 18:62-75.

Gray, R. Kouhy, R., and Lavers, S. 1995. Corporate Social and Environmental Report, Accounting and Auditing Journal, 8:47-77.

Guthrie, J., and L.D. Parker. 1990. "Corporate Social Disclosure Practice: A Comparative International Analysis", Advances in Public Interest Accounting, Vol. 3, pp. 159175.

Jo, H., dan Yongtae, K. 2009. Ethics and Disclosure: A Study of Financial Performance of Firm in the Seasoned Equity Offerings Market, Journal of Business Ethics, 80:855878.

Kasali, R. 2005. Managemen Public Relations. Jakarta. Ghalia Indonesia.

Margolis, J.D., \& Walsh, J.P. 2003. Misery loves companies: Rethinking social initiatives by business. Administrative Science Quarterly, 48: 268-305.

Mc.Guire, J. 1963. Business and Society. New York: McGraw-Hill.

Memed, S. 2001. Tanggungjawab Sosial Perusahaan dan Kaitannya dengan Pasal 33 UUD 1945, Konglomerat dan Sepak terjangnya, Kwik Kian Gie dan B.N. Marbun. Jakarta: Pustaka Sinar harapan.

Milne, M.J., and Adler, R.W. 1996. Exploring the Reability of Social and Environmental Disclosure Content Analysis, Accounting, Auditing and Accountability Journal, $1: 34-54$. 
Mittal, R.K., Sinha, N., and Singh, A. 2008. An Analysis of Linkage Betewen Economic Value Added and Corporate Social Responsibility, Management Decision Journal, 46:1437-1443.

Molina-Azorin, Jose, F., Enrique Claner-Cortes, Maria, D., Lopez-Gamero, dan Juan J. Tari. 2008. Green Management and Financial Performance : a Literature Review, Journal Management Decision, 47:1080-1100.

O’Donovan, G. 2002. Environmental Disclosure in the Annual Report: Extending the Aplicability and Predictive Power Legitimacy Theory, Accounting, Auditing and Accountability Journal, 15:344-371.

Poddi, L., dan Sergio, V. 2009. Did Corporate Social Responsibility Affect performance of Firm? Nota Di Lavoro, 52 University of Brescia.

Roida, H.Y. 2008. Relevansi program Corporate Social Responsibility bagi wacana publik: menjadi baik pada saat sudah menjadi buruk, the 2nd National Conference UKWMS, Surabaya, 6 September.

Sembiring, E.R. 2003. "Kinerja Keuangan, Political Visibility, Ketergantungan Pada Hutang, dan Pengungkapan Tanggung Jawab Sosial Perusahaan.” Makalah disampaikan pada Simposium Nasional Akuntansi VI, Surabaya, 16-17 Oktober 2003.

Siegel \& Paul. 2006. Corporate Social Responsibility and Economic Performance.https:// csr-udesc-esag.wikispaces.com/file/ view/ Paul - Siegel Economi Performance.pdf

Suman, agus (2010) Paradigma CSR . www.Bataviase.co.id. diakses tgl 30 Juni 2010.

Suta, I Putu Gede Ary. 2000. Menuju Pasar Modal Modern. Jakarta: Yayasan Sad Satria Bhakti.

Suta, I Putu Gede Ary. 2006. Kinerja Pasar Perusahaan Publik di Indonesia; Suatu Analisis Reputasi Perusahaan. Jakarta: Yayasan Sad Satria Bhakti.

Ullman, A.R. 1985. Data in Search of a Theory : a Criticl Examination of Relationships Among Social Performance, Social Disclosure and Economic Performance of US Firm, Academy of Management, 10:540-557.

Waddock, S.A., dan S.B. Graves. 1997. The corporate social performance-financial performance link, Strategic Management Journal 18:303-319.

Wibisono, Y. 2007. Membedah Konsep dan Aplikasi Corporate Social Responsibility. Fascho Publishing. Jawa Timur.

Yamaguchi, K. 2008. Static and Dinamic Return on Corporate Environmental Investement Activity : Emphirical Evidence from Japan, CSR Paper 36 Kobe University Japan.

Yang, Fu-Ju. 2010. The Linkage Between Corporate Social Performance and Corporate Financial Performance. African Journal of Business Management Vol. 4(4), pp. 406413.

Yoshikawa, T., Phan, P.H. 2003. Performance Implications Of Ownership-driven Governance Reform. European Management Journal 21(6), 698-06.

Undang-undang Republik Indonesia Nomor 19 Tahun 2003 tentang Badan Usaha Milik Negara.

Undang-undang Republik Indonesia Nomor 25 Tahun 2007 tentang Penanaman Modal.

Undang-undang Republik Indonesia Nomor 40 Tahun 2007 tentang Perseroan Terbatas. 